\title{
PERANAN GURU DALAM MEMBERIKAN BIMBINGAN TERHADAP ANAK DENGAN KEBUTUHAN KHUSUS DI SEKOLAH LUAR BIASA NEGERI 1 KOTA JAMBI
}

\author{
(The Role of Teachers in Giving Guidance to Children with Special Needs
}

In SLB State 1 Jambi City)

\author{
RANI ABDAH \\ SLB Negeri 1 Kota Jambi \\ Email: abdahrani.124@gmail.com
}

\begin{abstract}
All citizens are entitled to education for both normal children and children with special needs, in accordance with Law Number 20 of 2003 and confirmed in Permendiknas Number 70 of 2009 by providing opportunities for children with special needs to get guidance at school. This study aims to describe the role of the teacher in providing guidance to children with special needs, especially in individual development. This research uses descriptive method with literature study as a data collection tool. The results showed that the role of the teacher in providing guidance to children with special needs is very important. This role can be seen from the mastery of the teacher in providing counseling and individual development guidance which requires the teacher to creatively develop patterns and methods of approaching children. However, the educational background and commitment of teachers in providing guidance to children with special needs are key factors for children's success in developing themselves.
\end{abstract}

Keywords : Teachers, Children with Special Needs, Special Schools

\begin{abstract}
Abstrak
Semua warga negara berhak memperoleh pendidikan baik bagi anak normal maupun anak berkebutuhan khusus, sesuai dengan Undang-Undang Nomor 20 Tahun 2003 tentang Sistem Pendidikan Nasional dan dipertegas dalam Permendiknas Nomor 70 Tahun 2009 tentang Pendidikan Inklusif bagi Peserta Didik yang memiliki Kelainan dan Memiliki Potensi Kecerdasan dan/atau Bakat Istimewa, dengan memberi peluang kepada anak berkebutuhan khusus untuk mendapatkan bimbingan di sekolah. Penelitian ini bertujuan untuk mendeskripsikan bagaimana peranan guru dalam memberikan bimbingan terhadap anak dengan kebutuhan khusus terutama dalam pengembangan individu. Penelitian ini menggunakan metode deskriptif dengan studi kepustakaan sebagai alat pengumpul data. Hasil penelitian menunjukkan bahwa peran guru dalam memberikan bimbingan terhadap anak dengan kebutuhan khusus sangat penting. Peran tersebut terlihat dari penguasaan guru dalam memberikan bimbingan konseling dan pengembangan individu yang mengharuskan guru untuk kreatif mengembangkan pola serta metode pendekatan terhadap anak. Akan tetapi latar belakang pendidikan serta komitmen guru dalam memberikan bimbingan terhadap anak berkebutuhan khusus menjadi faktor kunci keberhasilan anak dalam mengembangkan dirinya.
\end{abstract}

Kata kunci : Guru, Anak dengan Kebutuhan Khusus, Sekolah Luar Biasa

\section{PENDAHULUAN}

Sekolah inklusi adalah sekolah reguler yang mengkoordinasi dan mengintegrasikan siswa reguler dan siswa difabel dalam program yang sama. Pendidikan inklusi adalah sebuah sistem pendidikan yang memungkinkan setiap anak penuh berpartisipasi dalam kegiatan kelas reguler tanpa mempertimbangkan kecacatan atau karakteristik lainnya. Penyelenggaraan pendidikan inklusi ditujukan memenuhi target pendidikan untuk semua warga negara dan 
pendidikan dasar sembilan tahun. Keuntungan penye-lenggaraan pendidikan inklusi adalah selain untuk memenuhi hak-hak asasi manusia, hak-hak anak, namun juga dapat mewujudkan kesejahteraan anak.

Selama ini anak yang memiliki perbedaan kemampuan (difabel) disediakan fasilitas pendidikan khusus disesuaikan dengan derajat dan jenis difabelnya yang disebut dengan Sekolah Luar Biasa (SLB). Secara tidak disadari sistem pendidikan SLB telah membangun eksklusifisme bagi siswa difabel. Eksklusifisme tersebut tanpa disadari telah menghambat proses saling mengenal antara anak-anak difabel dengan anak-anak non difabel. Akibatnya dalam interaksi sosial di masyarakat, kelompok difabel menjadi komunitas yang tereliminasi dari dinamika sosial di masyarakat. Masyarakat menjadi tidak akrab dengan kehidupan kelompok difabel. Sementara kelompok difabel sendiri merasa keberadaannya bukan menjadi bagian yang integral dari kehidupan masyarakat di sekitarnya.

Pada prosesnya, saat ini sekolah tingkat dasar tidak diperbolehkan mengadakan seleksi untuk menyaring calon siswanya, termasuk apakah siswa ini adalah siswa normal atau berkebutuhan khusus. Sehingga di lapangan ditemukan berbagai siswa berkebutuhan khusus yang mengikuti sistem pembelajaran reguler. Permasalahan ini sejalan dengan data dari Kemendiknas (2012), bahwa Anak Berkebutuhan Khusus (ABK) tahun 2010 kurang lebih sebanyak 1.544.184 anak dan hanya 330.764 anak dari jumlah tersebut yang mendapatkan layanan pendidikan di sekolah khusus (SLB) ataupun sekolah dengan program inklusif sehingga masih terdapat sekitar 245.027 anak $(74,08 \%)$ yang belum mendapatkan akses pendidikan.

Tulisan ini mencoba untuk menggambarkan bagaimana sebenarnya peran guru dalam mem-berikan bimbingan terhadap Siswa Berkebutuhan Khusus (SBK) di Kota Jambi khususnya di Sekolah Luar Biasa (SLB) Negeri 1 Kota Jambi. SLB N 1 Kota Jambi menjadi sampel karena berbagai permasalahan termasuk pengalaman dan kemampuan guru dalam membimbing langsung SBK sudah berjalan. Saat ini berdasarkan 
data di SLBN 1 Kota Jambi terdapat 21 Guru dan 270 SBK. Rata-rata guru berpendidikan Sarjana Pendidikan, namun belum ada guru yang khusus berlatar belakang pendidikan inklusi.

Menurut Undang-Undang Nomor 20 Tahun 2003 tentang Sistim Pendidikan Nasional, jenis pendidikan bagi ABK adalah Pendidikan Khusus. Namun dengan jumlah SBK yang melebihi kapasitas pendidikan khusus yang ada, menyebabkan masalah di lapangan. Kebanyakan siswa berkebutuhan khusus ini dipastikan memasuki sekolah dasar yang bersifat reguler.

Gambaran SBK yang mereka tangani adalah misalnya siswa dengan gangguan atensi dan hiperaktifitas yang biasanya dapat menggangu dan membuat situasi belajar menjadi tidak kondusif dan ada juga siswa lambat belajar (slow learner) dan siswa mental retardasi ringan, sehingga lambat dalam menangkap dan memahami pelajaran. Untuk mencapai pembelajaran yang efektif dan kondusif sehingga tujuan pembelajaran tercapai dengan baik maka guru dituntut untuk mampu memberikan penanganan secara langsung ketika pembelajaran berlangsung. Oleh karena ini, kesiapan dan peran guru dari pihak sekolah dasar, khususnya guru untuk menangani pengajaran pada SBK menjadi tombak utama dalam mengentaskan pendidikan bagi anak dengan kebutuhan khusus.

\section{LANDASAN TEORI}

Permendiknas RI Nomor 70 Tahun 2009 tentang Pendidikan Inklusif bagi Peserta Didik yang Memiliki Kelainan dan Memiliki Potensi Kecerdasan dan/atau Bakat Istimewa, Pasal 1 dalam Garnida (2015) menyatakan bahwa pendidikan Inklusif didefinisikan sebagai "sistem penyelenggaraan pendidikan yang memberikan kesempatan kepada semua peserta didik yang memiliki kelainan dan memiliki potensi kecerdasan dan/atau bakat istimewa untuk mengikuti pendidikan atau pembelajaran dalam satu lingkungan pendidikan secara bersama-sama dengan peserta didik pada umumnya".

Schultz (1994) dalam Garnida (2015), telah menemukan kategori prasyarat bagi sekolah yang ramah dan inklusif salah satunya adalah sikap guru dan sekolah yang harus memiliki 
keyakinan akan menghasilkan proses pengajaran dan pembelajaran yang meningkat bagi semua orang. Lingkungan sekolah, khususnya guru perlu menunjukkan persahabatan dan kerjasama antara siswa dengan atau tanpa hambatan harus dipandang sebagai suatu norma yang berlaku.

Guru juga perlu memberikan dukungan bagi siswa yang diperlukan untuk memberikan layanan kebutuhan bagi SBK. Pihak sekolah juga perlu memberikan dukungan kepada guru untuk memiliki kesempatan latihan yang dapat digunakan dalam menangani jumlah keberagaman siswa. Kepala sekolah dan staf lain harus pula memberikan dukungan dan kepemimpinan di sekolah yang lebih inklusif. Kurikulum harus cukup fleksibel dengan pencapaian dan tujuan belajar harus diberi penilaian yang memberikan gambaran kemampuan siswa (Garnida, 2015).

Dalam pembelajaran inklusi, peran guru sangatlah penting karena merupakan tonggak proses pembelajaran. Kegiatan pembelajaran di sekolah yang bersifat inklusi perlu memiliki kemampuan menerapkan kurikulum yang bersifat heterogen. Langkah yang perlu dipersiapkan guru dalam penyelenggaraan pendidikan inklusi adalah sebagai berikut (Hamalik, 2011 dan Garnida, 2015). :

(1) Perencanaan pembelajaran disesuaikan dengan kebutuhan siswa-siswi dengan mengacu pada kurikulum yang disesuaikan. Guru mampu me-nyusun rencana program pembelajaran individual (PPI) yang mampu memodifikasi kurikulum disesuaikan kemam-puan anak didik;

(2) Proses pembelajaran dilaksanakan sesuai dengan kondisi dan kemampuan siswa-siswi yang menekankan pada proses belajar yang optimal. Pem-belajaran dapat bersifat fleksibel dengan melihat pada kemajuan anak;

(3) Penilaian meliputi pengukuran terhadap materi yang telah dipelajari dengan standar individual pada kemampuan dasar yang harus dikuasai; dan

(4) Pengawasan pembelajaran dilakukan tidak hanya oleh pihak sekolah namun bekerja sama dengan orang tua dan lingkungan masyarakat. 


\section{METODE PENELITIAN}

Metode yang digunakan adalah studi kepustakaan, menurut Nazir (2003), "studi kepustakaan adalah teknik pengumpulan data dengan mengadakan studi penelaahan terhadap buku-buku, litertur-literatur, catatan-catatan, dan laporan-laporan yang ada hubungannya dengan masalah yang dipecahkan". Peneliti melakukan kajian yang berkaitan dengan teori yang berkaitan dengan topik penelitian, mengumpulkan informasi sebanyak-banyaknya dari kepustakaan yang berhubungan. Sumber-sumber kepustakaan dalam penelitian ini diperoleh dari buku, jurnal dan hasil-hasil penelitian. Sehingga dalam penelitian ini meliputi proses umum seperti mengidentifikasikan teori secara sistematis, penemuan pustaka dan analisis dokumen yang memuat informasi yang berkaitan dengan topik penelitian.

\section{HASIL DAN PEMBAHASAN}

Sekolah dasar adalah fondasi bagi pendidikan selanjutnya. Dengan memahami kondisi ini, maka betapa penting memberikan pelayanan pendidikan yang sebaik-baiknya di tingkat Sekolah Dasar (SD) dan berusaha mengembangkan potensi anak dengan sebaik-baiknya. Proses pembelajaran yang memerlukan perhatian bukan hanya proses pembelajaran reguler saja, namun juga perlu diperhatikan proses pembelajaran bagi siswa berkebutuhan khusus. Deklarasi dunia tentang Pendidikan Inklusi menuntut tanggap kerja semua komponen pada lembaga pendidikan untuk melaksa-nakan tugas melayani anak, khususnya ABK (Tyas, 2016).

Semua anak, baik cacat maupun tidak mempunyai hak untuk belajar bersama-sama dengan anak yang lain. Seyogyanya anak tidak diberi label atau dibeda-bedakan secara rigid, tetapi perlu dipandang bahwa mereka memiliki kesulitan dalam belajar. Tidak ada alasan yang mendasar untuk memisah-misahkan anak dalam pendidikan.

Anak memiliki kebersamaan yang saling diharapkan di antara mereka. la tidak pernah ada upaya untuk melindungi dirinya dengan yang lain. Penelitian menunjukkan bahwa anak cenderung menunjukkan hasil yang baik secara akademik dan sosial bila mereka berada pada setting kebersamaan. 


\section{Bimbingan dan Konseling Sebagai Layanan Bagi Anak Berkebutuhan khusus}

Layanan bimbingan dan konseling dalam proses pendidikan berkaitan erat dengan makna dan fungsi pendidikan. Perlunya layanan bimbingan dan konseling dalam proses pendidikan bila dipandang bahwa pendidikan merupakan upaya untuk mencapai perwujudan manusia sebagai totalitas kepribadian. Kualitas manusia yang dihasilkan melalui pendidikan merupakan andalan bagi tercapainya tujuan pembangunan nasional. Kualitas yang dimaksud adalah suatu pribadi yang paripurna, yaitu pribadi yang serasi, selaras dan seimbang dalam aspek-aspek spiritual, moral, sosial, intelektual, fisik dan sebagainya. Dengan demikian tujuan pendidikan tidak lain adalah perkembangan kepribadian secara optimal dari setiap subyek didik.

Bagi anak yang mengalami gangguan mental, ukuran optimal lebih pada kemampuan mengurus diri sendiri, bagi yang mengalami kelainan fisik kemungkinan sekali ukuran optimal dapat mendekati ciriciri kepribadian sesuai dengan apa yang menjadi tuntutan diri dan lingkungannya, sedangkan bagi anak gifted kemungkinan besar ciri-ciri pribadi yang optimal tersebut dapat tercapai. Untuk mencapai pribadi yang berkembang secara menyeluruh, kegiatan pendidikan hendaknya bersifat menyeluruh, yaitu tidak hanya kegiatankegiatan intruksional dan kegiatankegiatan administrasi tetapi meliputi kegiatan yang menjamin bahwa setiap anak didik secara pribadi mendapat layanan, sehingga perkembangan yang opti-mal dapat terwujud. Layanan pribadi tersebut dapat dipenuhi melalui bimbingan dan konseling.

Pemberian layanan bimbingan dan konseling merupakan bagian bagi asuhan kepada ABK. Untuk melayani anak dengan sepenuh hati agar bisa mengambil hati sang anak.di SLBN 1 Kota Jambi sudah ada program yang menangani bimbingan konseling terhadap ABK. Walaupun ada petugas khusus yang ditunjuk, namun masingmasing guru memiliki kewajiban untuk membe-rikan bimbingan dan konseling. Dengan cara pendekatan-pendekatan, seperti pendekatan krisis, remedial, perkembangan serta pencegahan. Pada hakikatnya, guru bisa sebagai konselor utama selain orang tua di rumah. 


\section{Bimbingan Terhadap Perkembangan Individu}

Proses perkembangan individu dipengaruhi oleh berbagai faktor, baik yang berasal dari dalam maupun yang berasal dari luar atau lingkungan. Faktor dari dalam diri individu, perkembangan dipengaruhi oleh pembawaan (potensi) dan kematangan, sedangkan dari luar perkembangan individu dipengaruhi oleh faktor lingkungan fisik, lingkungan sosial dan nutrisi.

Perkembangan dapat berhasil bila faktor-faktor tersebut saling mengisi dan melengkapi. Untuk itu diperlukan usaha berupa asuhan yang terarah. Asuhan dalam perkembangan melalui proses belajar disebut pendidikan. Pendidikan sebagai salah satu bentuk lingkungan bertanggung jawab memberikan asuhan terhadap jalannya proses perkembangan individu. Bimbingan yang merupakan salah satu bagian pendidikan merupakan bantuan individu untuk memperoleh penye-suaian diri sesuai dengan tingkat perkembangan.

Dalam hubungannya dengan tingkat perkembangan, individu mempunyai seperangkat tugas perkembangan (development task), yaitu penguasaan seperangkat pengetahuan dan keterampilan yang harus dikuasai individu pada satu periode perkembangan tertentu sebagai dasar untuk memasuki periode perkembangan berikutnya. Penguasaan tugas-tugas perkembangan pada periode sebelumnya berpengaruh terhadap penguasaan tugas-tugas perkembangan berikut-nya. Melalui bimbingan, individu dibantu untuk mencapai penguasaan tugastugas perkembangan pada periode perkembangan yang dilaluinya sehingga mereka memperoech penyesuaian pada setiap periode perkembangan yang akhirnya akan memperoleh penyesuaian yang optimal.

Untuk memberikan bimbingan terhadap perkembangan individu, guru di SLB Negeri 1 Kota Jambi secara berkala telah diberikan pelatihanpelatihan baik secara formal maupun non formal. Secara formal pendidikan dan pelatihan terutama dalam pengembangan kurikulum serta pola dan metode pendekatan bagi anak berdasarkan kondisi anak. Non formal, pelatihan seperti meningkatkan 
kreativitas guru dalam membimbing anak melalui aktivitas pembuatan kerajinan tangan untuk mengembangkan potensi ABK.

Walaupun beberapa pelatihan telah diberikan kepada guru di SLB, Ward (1987) dalam Jamilah (2015), bahwa penolakan dari guru dan lemahnya dukungan terhadap anak berkebutuhan khusus disebabkan karena kurangnya pemahaman dan pengetahuan tentang anak dengan kebutuhan khusus. Latar belakang pendidikan yang tidak memberikan bekal kepada guru tentang anak berkebutuhan khusus menjadi penyebab guru di sekolah luar biasa kurang memahami kebijakan sekolah berkebutuhan khusus.

Guru di SLB N 1 Kota Jambi menganggap diri mereka masih kurang memiliki keterampilan untuk mengajar siswa dengan berbagai kebutuhan khusus, namun segala upaya telah dilakukan untuk melaksanakan berbagai program bagi anak berkebutuhan khusus di kelas mereka. Hal ini akan berpengaruh terhadap penerimaan guru dan perlakuan guru. Sikap yang ditunjukkan guru akan mempengaruhi penerimaan anak berkebutuhan khusus. Dengan demikian komitmen guru di sekolah menjadi salah satu faktor yang paling penting dalam keberhasilan atau kegagalan program-program pengembangan individu.

\section{KESIMPULAN}

Peran guru dalam memberikan bimbingan terhadap anak dengan kebutuhan khusus sangat penting. Peran tersebut terlihat dari penguasaan guru dalam memberikan bimbingan konseling dan pengem-bangan individu yang mengharuskan guru untuk kreatif mengembangkan pola serta metode pendekatan terhadap anak. Akan tetapi latar belakang pendidikan serta komitmen guru dalam memberikan bimbingan terhadap anak berkebutuhan khusus menjadi faktor kunci keberhasilan anak dalam mengembangkan dirinya.

\section{DAFTAR PUSTAKA}

Garnida, Dadang. 2015. Pengantar Pendidikan Inklusif. Bandung : Refika Aditama.

Hamalik, Oemar. 2011. Proses Belajar Mengajar. Jakarta : Bumi Aksara

Jamilah Candra Pratiwi. 2015. Sekolah Inklusi Untuk Anak Berkebutuhan Khusus: Tanggapan Terhadap Tantangan Kedepannya. Prosiding Seminar Nasional Pendidikan. Pendidikan Guru 
Sekolah Dasar, Program Pascasarjana UNS.

Rika Ariyani.2018. Kepemimpinan Kepala Sekolah Dalam Meningkatkan Kinerja Guru SLB (Studi Kasus Di SLB Buah Hati Jambi) Jurnal An-
Nahdhah,

1 Januari - Juni 2018

Vol. 12 No.

Tyas MA, Rischa PT,. 2016. Kompetensi Guru Pendamping Siswa ABK di Sekolah Dasar. Jurnal Konseling GUSJIGANG Vol.2 No.2 Juli-Desember 2016 